\title{
Muslim and Mosque in Postcolonial Text
}

\author{
Rashad Mohammad Moqbel Al Areqi ${ }^{1}$ \& Hussein Saleh Al Bahji ${ }^{2}$ \\ ${ }^{1}$ English Department, Sana'a Community College, Sana'a, Yemen \\ ${ }^{2}$ English Department, University of Science and Technology, Sana'a, Yemen \\ Correspondence: Rashad Mohammad Moqbel Al Areqi, English Department, Sana'a Community College, \\ Sana'a, Yemen. E-mail: alarikirashad@yahoo.com
}

Received: November 2, 2013 Accepted: December 2, 2013 Online Published: February 22, 2014

doi:10.5539/ells.v4n1p54 URL: http://dx.doi.org/10.5539/ells.v4n1p54

\begin{abstract}
The article explores the image of the Muslim and the mosque in postcolonial literary texts. E. M. Forester's $A$ Passage to India is taken as an example of the postcolonial text which will be traced to recognize how the western novelist portrays the Muslim's life and how he has shaped the indigenous identity of the Muslim in this narrative. Further, the article highlights the Muslim's relationship with non-Muslim in India, whether they are Indians or English people and its repercussions in their daily lives. Forster's visit to India and his real experience would help him to reflect the reality of the situation in India. How Forster does manifest the Muslim and the mosque in this narrative? How does Dr. Aziz receive the strangers, particularly, the English people, the colonizers who are different in their culture and religion? In addition, what are the Islamic values incarnated by Dr. Aziz in the novel? The argument focuses on Dr. Aziz as a Muslim and his relationship with the mosque in the text. The article found that Muslim represented by Dr. Aziz as a true believer and a respectful character in the world of difference and diversity as Mrs. Moors represented the brilliant side of Christianity and the human side of British colonizers in India. Aziz's manifestations of counter discourse are argued throughout the narrative and Dr. Aziz's loyalty to the mosque, faith, and to his country is unquestionable.
\end{abstract}

Keywords: Muslim, Mosque, colonizers, colonized, tolerance, cultural conflict, discrimination, identity

\section{Introduction}

A Passage to India is a famous novel written by E. M. Forester during the English colonization of India. Forester's two visits to India and his good relationship with a Muslim friend from India have shaped the framework of this novel. In investigating of the historical facts, Britain worked on developing different areas of agriculture, industry in India and continued establishing more railroads that made India had the longest railroad in the area. However, Indians could not see in that development just achieving the British interests in India and the Indians citizens were under the second-class status that would not let them benefit from such progress at their personal lives. The Indians felt that the privileges granted only to the British people in India and how British as colonizers had treated Indians as second-class status. All those events led the Indians to revolt against the British rule in India. Their demand for independence became striking power could not be ended easily. As a result, Indian National Congress was established to unite the Indians' efforts to gain their lost rights. However, the influence of the independence movement getting stronger and invaded a large segments of Indian people who were longing for freedom.

Britain's involvement in the First and Second World Wars encouraged Indians to take advantage of the vulnerability of the British Empire to escalate their political struggle to reach their independence. Mohandas Gandhi led the resistance movement and he became the voice of the India National Congress whose efforts came to success at the end of the World War II when Britain gave its promise to the independence of India. The clashes between Muslims and Hindus initiated to separate the large sub-continent into Muslim state in the North, Pakistan, and Bangladesh in the Northeast. The events of the novel took its place in India and the writer was a British writer who was determined to give a deep insight into the relationship between British and Indian under the British occupation in India. A Passage to India does not represent only the Indian milieu, but it also spots the light on the British people in India and their treatment to the natives, the colonized. Forster's first visit to India was in (1912-1913) and he finished writing the novel in 1924. Britain at that time had undergone a bitter experience of world war I. Britain and its allies won the war with sacrificing more than 750,000 British soldiers. Those losses alter people's attitudes towards the British position in the world as undefeated power and its 
potential to survive.

A Passage to India was written during a time of escalated tension between the British and the natives in India. Forster visited India twice and wrote another novel, Maurice, before finally completing A Passage to India in 1924 - more than ten years after it begun. The novel addresses thematic issues such as friendship of the natives with British people, the relationship between the West and the East, between the colonizers and the colonized, practice racism against the natives, the image of Muslim in the western eyes and Muslim's relationship with the people of his community marked with difference and diversity. In this novel, Forster highlights the Muslim's attitudes towards the colonizers and towards life in general. Baker (2006) pointed out that "Forster's India is hostile to foreigners and attacks its colonizers furiously, so as to force them to leave. Despite the British attempts to 'tame' India, it remains wild country" (p. 70). This is clear when Dr. Aziz refuses the friendship with the colonizers represented by Mr. Fielding's request to renew their friendship.

The argument focuses on Muslim and the mosque position in A Passage to India as a postcolonial text. How does a British writer depict Muslim and his involvement with the mosque as a symbol of Muslim's place of worshipping? How does a Muslim as Dr. Aziz who will be the focus of this study reflect Islamic values and Islamic culture in his daily activities? Dr. Aziz managed to establish his position and reputation in a community full of contradictions in cultures, religions and social conventions. Dr. Aziz is the most significant character discussed in the novel and his relationship with Muslim and non-Muslim in his country is argued in the narrative as well as his relationship with the British metropolitan power in India. From the beginning, Forster raises a question between Dr. Aziz and his Muslim friends about the possibility of making a friendship with the colonizers "whether or not possible to be friends with an English man." The answer is given by Forster himself at the end of the novel" No, not yet-No, not there" (p. 141). The course of the events reveals Dr. Aziz as a friend to two English women, Mrs. Moor and Miss Adela Quested beside his friendship to an English Principal of the college, Mr. Fielding. Forster does not want to establish a fake bridge between the colonizers and the colonized, the reality of the situation in India could not admit such relationship. Forster intends to depict the metropolitan domination over the Indians explicit and the reader may realize it through the lines of the narrative. Len (1997) argued "Forster's ideological indeterminacy is primarily rooted in the humanist perception of cultural identity, a perception that tends to reinforce cultural distinctiveness, difference and distance in the arena of intercultural positioning and in so doing provides the epistemic basis for the historical emergence of colonial expansion" (p. 133).

The focus here is on Muslim indigenous identity presented by Dr. Aziz and the counter discourse which is used to maintain his indigenous identity as an Indian Muslim identity. The mosque and Dr. Aziz symbolize the counter discourse that would not dissolve under the British domination. These two concepts of postcolonial theory are traced to recognize the image of Muslim and how he struggles to resist reconstruction of his identity despite Dr. Aziz, as a Muslim, studied in the metropolitan country and his relationship with the British colonizers is explicit. He managed to adhere to his culture, religion and he established a very good reputation among different segments of his country's people. The two concepts are traced in the acts and actions of Dr. Aziz as a Muslim who is concerned about his culture and religion. How does Dr. Aziz manifest his character in his small community of Indian Muslims in particular and in the big community of India marked by difference and diversity in general? However, Indians appear in the novel bear the same concern of their country decolonization regardless of their different race or religion, "Hindu, Muslim, Sikh, and all shall be one! Hurrah! Hurrah for India" (Forster, 1985, p. 141). They would not tolerate or offer concession about their country independence.

Counter discourse is a term used by Richard Terdiman to mark the theory and practice of resistance, Terdiman explores the means of producing genuine transformation against "the capacity of established discourses to ignore or absorb would-be subversion" (Ashcroft et al., 2002). This concept is used by postcolonial writer to reflect the indigenous people's resistance against the colonizers' domination on the different aspects of their lives. In $A$ Passage to India, Dr. Aziz's counter discourse has been embodied in his acts and action throughout the narrative. Aziz nationalist situation is not questionable. All manifestations of Aziz's life consider in one way or another discourse analysis that stands against the existence of colonizers on his land. Dr Aziz is revealed liberal in his contact with the other and his respect to the other cultures and conventions is clear, however, he is stuck to his Islamic principles and his local culture.

The indigenous identity and the counter discourse are revealed by Forster in many parts of the novel. Forster gives the Indians, particularly Muslims, a powerful voice to make the voice of their freedom hearable to make the Indians Muslims stand against colonizers' reconstruction of their identity. The crossroad between Indians and British would not be established because the colonizers pay no attention to specialty of the culture, conventions and the religion of Muslim Indians. Colonizer's ignorance is embodied in Adela Quested's questions to Dr. Aziz 
in the cave about the wife, the religion and other personal questions that make Dr. Aziz disturbed. Dr. Aziz's counter discourse is revealed in many parts of the novel, particularly, his meeting with Mr. Fielding after very long absence. Dr. Aziz does not admit the colonizer's friendship, friendship between Dr. Aziz and Mr. Fielding regardless the later personal attitude towards Indians. In many situations, Mr. Fielding was the defender of Dr. Aziz's innocence after he is accused by one of the British women, Adela Quested, whose name highlights, by Forster, something, requires to be searched in her character; something vague leads her to hallucinations. Muslim, non-Muslim and every place in India would not admit the existence of colonizers on their land. Muslim indigenous identity manifests resistance to the colonizers' attempt to reshape their indigenous identity. Aziz would not jeopardize his Islamic values and principles for earthly interests. Aziz's identity as a Muslim is striking as portrayed by Forster in many situations in this narrative such as his first meeting with Mr. Moors at the mosque and Adela Quested in the cave which have reflected his concern about his culture and religion. He does not give his lust an opportunity to prevail.

\section{Muslim and Involvement with the Mosque}

The first part of the novel has been given a title of "the Mosque" to highlight the significance of the mosque in Muslim Indian lives as a sacred place of worshipping. Forster recognizes well the sacredness of such places for Muslim and in what way he manifests the sacredness of such worshipping places in the lives of Muslim. The touching part of this section contains the contact between the West and the East, between Christianity and Islam that meeting coincidently occurred in the mosque between Mr. Moors as a Christian woman and Dr. Aziz as a Muslim Indian. The first meeting between Dr. Aziz and Mr. Moors has left very good impression from both sides despite the big gap between their cultures and religions after misunderstanding at the first sight.

The argument concentrates on Mrs. Moors and Dr. Aziz in the first meeting that would uncover the reality of Muslim image and his attitude towards the other cultures and religions, even if those people represent the dominating power and the occupying colonizers in his country. The second part of argument will be directed to the caves' section and the troubling events occurred inside them. The novel dramatically portrays the conflict between Indian people particularly Muslims and metropolitan power, simaletenously, the relationships between different races and religions in India. Forster (1985) argues in this novel the position of Muslim and the Mosque in Indian community that undoubtedly has a very big space in the hearts of undeniable segment people of India, "A mosque by winning his approval let loose his imagination. The temple of another creed, Hindu, Christian, or Greek, would have bored him and failed to awaken his sense of beauty-here was Islam, his own country, more than a faith, more than a battle cry, more, much more" (p. 6). From above lines, we recognize that Islam has its significance in the hearts of Muslims and in the land of India, which is Hindus-dominated state, despite existence of other religions and races. However, Islam and Muslim gain respect among the people of India as a religion embraced by millions of Indians. "Islam an attitude towards life both exquisite and durable, where his body and his thoughts found their home" (p. 6).

A Passage to India addresses a question of faith in culture and social conventions. When the colonized embodied by Dr. Aziz's attempts to establish a sort of friendship with the colonizers, it ended with disastrous consequences as Dr. Aziz is accused of attempting to rape an English woman. Dr. Aziz a Muslim Indian doctor is befriended by Mrs. Moors and Miss Adela Quested, two recently arrived women. Forster introduces the Indians voices and exposes problematic issues about how metropolitan power mistreats the natives, addressing them from superior perspective and Forster explicates in this novel his sympathy with the natives. It is not hidden the superiority that the British colonizers takes upon themselves in this novel, sequestering themselves in the British club that no more Indians can be a part of it. Ronny as a British magistrate is a parody of the colonizers whose concern only in responding to the British demands even if they come against humanity and ethics. He dehumanizes himself and puts himself as a god to hold the country by force. "He did rub it in that he was not in India to behave pleasantly, and derived positive satisfaction there from ... the traces of young man humanitarian sloughed" ( $p$. 52).

The first meeting between Dr. Aziz and Mrs. Moors in the mosque unmasks the personality of Dr. Aziz as a Muslim who would not victimize his sacred rituals. When he sees non-Muslim women in the Mosque and may be enter without taking off her shoes, you find him furiously crying "Madam! Madam! Madam!" 'Oh! Oh! "The woman gasped."Madam this is a mosque, you have no right to be here at all, you; you have taken off your shoes, this a holy place for Muslim." "I have taken them off." You have. I left them at the entrance." Then I ask your pardon" (p. 6). Here, you can realize the value and the position of the mosque in the hearts of Muslim, it is a place of God, Dr. Aziz's anger could not be concealed and is revealed explicitly in the tone of his voice and the repetition of the words to make that strange woman hear his warning. He could not imagine seeing non-Muslim woman in the mosque to tarnish its sacredness. Aziz appeared as a jealous Muslim who could not tolerate any act 
or action that devalue Muslim places of worshipping. Dr. Aziz's reaction comes spontaneously and directly that expresses a live faith in the heart of this Muslim, a Muslim who adhered to his religion's teachings and orders. He could not admit any tolerance if it comes at the expense of Muslim's holy places like the mosque and his anger makes the reader realize that the position of sacred places in his heart and his defense of such sacred places is a mark of truthful faith.

The tone of Dr. Aziz has been softening as soon as he recognizes that Mr. Moors has taken off her shoes at the entrance and he recognizes that she is new in the country. She might not realize the sacredness of such places and simultaneously, he explicates the reasons of his anger. "This is a holy place for Muslim" (p. 6). Dr. Aziz sets a good example for the real Muslim who is concerned about his religion and place of worshipping as a mosque. The colonizers look at the natives as silent voices and easily may be ignored, but here Forster gives the colonized a voice to defend their rights and to express their attitudes and feelings regardless the colonizers' practices of metropolitan domination and oppression. Undoubtedly, Forster highlights the first meeting between Dr. Aziz as a colonized and Mrs. Moors as a colonizer, between the Christianity represented by Mrs. Moors and Dr. Aziz who embodied Islam, to lead us to recognize how Dr. Aziz becomes tolerant since he recognizes the circumstances of Mrs. Moors' existence in such place. This scene ends by Dr. Aziz's words that unveil a sort of more understanding to the religion and the culture of the other. Mrs. Moors appeared humble to confess her existence in the wrong place and announce, "Then I ask your pardon" to bring Forster the West and the East closer to each other, but he attempts to harmonize the relationship between the colonizers and the colonized. Mrs. Moor is revealed more delicate to emphasize her respect to others religious and social conventions. Forster wants to give an opportunity for tolerance and understanding to take place in the lives of both countries, Britain and India, However, he fails to bring the two parties together. Dr Aziz represents Muslim in an appropriate way while Mr. Moors manifests the good side of the colonizers. Mrs. Moors' son, is not like his mother, Ronny is a parody of racist attitudes towards Indian people. Mrs. Moors asserts, "India is a part of the earth and God has put us on the earth to be pleasant to each other. God ... is ... love ... God has put us on the earth to love our neighbors and how to show it, and he is omnipresent, even in India, to see how we are succeeding" (p. 24).

By such words, Mrs. Moors reveals the good understanding to the message of her religion, which is the message of God everywhere, and she looks at Indians as their neighbors who deserve love and respect regardless their race or religion. God's message is the same in every part of the earth and India is a part of this world. She shows respect to the other religion, culture and diversity. Her understanding and her son's discrimination pushed her to blame him, but to rebuke him for his ill-treatment with the Indians. Mrs. Moors reflects the humanity of the colonizers and the mercy of human towards the other human. By this positive attitude, the good relationship would be established between the nations if mutual respect and understanding prevail in the lives of the people. The message of God is to spread love and tolerance among the people, to understand their differences and respect their beliefs. Then definitely, the nations will enjoy peace and prosperity in their lives, away of hate and hatred.

Another attempt to bring the two parties together, the British and the Indians, is the Bridge Party, it was not a real attempt to bridge the gap between the colonizers and the colonized. This evidence could be read from Mrs. Turton's words about joining the native women to the party. "What do you want me to do? Oh, those purdah women! I never thought any would come. Oh, dear" (p. 27). From these lines, we realize that there is no real effort exerted to bring the two cultures together. The bridge party was a failure and it was not helpful for Miss Adela and Mrs. Moore to see the real India, that India they like to experience themselves. Dr. Aziz is very understanding to the diversity of his country. He does not hesitate to establish a good relationship with non-Muslims in his neighborhood. He has very good connection with Godbole, Indian Hindus, who believes in many Gods. He shares with him the tea in Mr. Fielding's house and he has to attend the celebration of his God's day. He listens to his words and songs with respect whatever they are. Dr. Aziz managed to build strong relationship with Muslim and non-Muslim, with Indian and British in India. His good reputation and good mannerism make the people with their different races and religion defend him and deny the accusation of Adela Quested of attempting to rape her. However, Godbole represents non-Muslims in the narrative, he has not been revealed in clear and strong situations as Dr. Aziz who is very clear in his social, national, and religious situations that bring to him respect among all races and in all places. Godbole seems vulnerable and has no clear vision about his acts and actions. He believes in many Gods and his words about them bring fun to the listeners. Forster categorizes the "Temple" as the last part of the novel, while the real end of the novel ends by the last part of the "Caves" and the events initiate to take another trajectory.

The second British individual who establishes a good relationship with the Indians is Mr. Fielding, a principal in a college, who presents the rationality of the colonizers. He acts from the beginning as a friend to Dr. Aziz, the 
natives and manifests more understanding and sympathy to Indians despite their difference and diversity. He always attends the Indian occasions and he is strong enough to defend his views against his people, British. Forester himself unveils the real intention in writing A Passage to India to Masoud, his friend, in 1922, "When I began the book I thought of it as a little bridge of sympathy between East and West, but this conception had had to go, my sense of truth forbids anything so comfortable. I think the most Indian, like most English people, are shits, and I am not interested whether they sympathize with one another or not" (p. 15).

From Forster's perspective, he could harmonize the text to bring the East and the West together. He finds that it is not easy task to fabricate that harmony between the colonized and the colonizers. Ronny is Mrs. Moore's son who lives with ecstasy of domination and he does not show any flexibility and sympathy with the colonized. He sees that the natives should be treated bad to remain submissive to the colonizers. He addresses his mother "what do you and Adela want me to do? Go against my class, against all the people I respect and admire out here! Lose such power as I have for doing good in this country, because my behavior is pleasant" (p. 69). Ronny could not conceal his hate and hatred for the colonized, his racism manifests itself through his words, he does not go against his people who respect, and namely, he does not bear respect and admiration to the colonized. Ronny could not find safety and security in India despite he is a symbol of security in India. He was not satisfied when his mother told him about her conversation to one of the natives. He was a Mohammedan. He does not like his mother's contact with Muslim, Mohammedan. Adela and Mrs. Moore want to push Ronny to the logic. Muslim in such situation, undoubtedly, will show his respect to the others' beliefs "would expect a Mohammedan to answer if you asked him to take off his hat in the church." Ronny "It is different, it is different; you don't understand" Ronny could not admit the reality of religions' respect and for this reason he does not feel comfort that reflects his post and position in India. India would not grant him that stability and peace he supposed to obtain so he shows that "India isn't home" (p. 54).

Ronny is not like his mother who responded positively to Dr. Aziz's cry. Her belief in Christianity could not affect her judgment upon the others who would not embrace her religion. She resists colonizers' discourse, even if this discourse represented by her son who reveals no respect to other culture and religions. She recognizes well that there is something in common that makes the people live together and respect the others. "India is a part of the earth. And God has put us on the earth in order to love our neighbors and to show it, and He is omnipresent, even in India, to see how we are succeeding" (p. 70). "God is love" (p. 70). She announces that God requests to spread love among all the people with their difference and diversity. Despite the colonizers' allegation of coming to civilize the native, Ronny points out "we're here to do justice and keep the peace-there's my sentiments." However, he goes against his claims of civilization and justice in which appeared in his racism practiced against Indians, "Ronny approved religion as long as it addresses the National Anthem, but he objected when it attempted to influence his life" (p. 21). Moosavinia (2011) argues, "Forster undermines the basic values of the West. He questions Christianity as an inefficient religion and western civilization as inadequate yard-stick of evolution" (p. 69).

\section{The Caves: Mysterious Journey}

The novel begins with the section of the Mosque, but actually, the first lines of the novel describe Marabar caves, the hidden truth, and the city of Chandrapore. Everything in the caves is blurred with mystery and ramifications of the cave lead any one to be lost in its darkness. The narrator reveals the caves as "fist and fingers". Forster finds the differences and diversity of India as ramifications of the caves. It is vague, it is not easy to realize everything around you, and the echo of the caves increases the puzzles crammed in the mind about the place and the people. Forster leaves the reader lost without any solution for what happened in the mysterious caves with Mrs. Moore, Dr Aziz and Miss Adela Quested. What happened in the caves remained puzzled and the caves themselves symbolized vagueness of colonizers' life in India and their misjudgment of Indian cultures and religions. Mrs. Moore felt unstable and could not continue this journey because she appears from the beginning clear as a woman who is stuck to her religion, Christianity. She was very clear about her beliefs and values towards the other religion or other culture when she was arguing with her son about the God's message to all people, which can be briefed in "God is love". Adela Quested's hallucinations drive her to accuse Dr. Aziz of attempting to rape her inside the caves. The argument here about Adela's hallucination created by her dark background about the natives. What she heard from her people, the colonizers, is not genuine. For this reason, she looks for the real India that she could experience herself, away of her people's allegations. "she was desirous of seeing the real India." (Forster, 1985, p. 9). India contains a variety of cultures and religions. However, what she heard about India could not be obliterated easily. She projects in her mind false stories about the bad people of India, particularly, Muslims. From the beginning, Dr. Aziz as Muslim is revealed as a respectful person among the different segments of Indian community with their differences in faith and cultures. 
Dr. Aziz is a doctor graduated from an English university and his Muslim friends as well: Mahmoud and Hamidullah who have accomplished their study in the colonizers' country, but they are manifested more liberals than the others, but their contact with the metropolitan power could not alter their concepts about religion and culture of their motherland. Forester in his realistic description of India is of unique interest. His artistic talent enabled him to impose metropolitan power on the reader and take their domination for granted, simultaneously, he took the natives resistance and rejection of colonizers' domination seriously. Forster puts the picture unmasked for the reader to make his own judgment and assessment. In the caves, Mrs. Moore faints when she finds herself crammed in dark and loses sight of Adela Quested and Dr. Aziz. She feels something strikes her face and hears a terrifying echo, "The echo in a Marabar cave is ... entirely devoid of distinction. Whatever is said, the same monotonous noise replies, and quivers up and down the walls until it is absorbed into the roof." (p. 64).

Dr. Aziz as a Muslim and his reaction to Miss Adela disturbing questions in the caves cast suspicions on her intentions. She asked him about his wife and the possibility of marrying four women in Islam. "But to ask an educated Indian Muslim how many wives he has - appalling, hideous!" (p. 69). Adela inadvertently offends Dr. Aziz by asking such questions that leaves him disturbed and slips into one of the caves to find himself alone "to recover his balance". Under bad impression about the natives, she expects that Dr. Aziz has followed her in an attempt to rape her. Forster scatters many evidences in the novel that prove Dr. Aziz's innocence. The first one, Dr, Aziz appears as a real Muslim who is concerned about the orders and teachings of Islam from the beginning of the novel. His treatment with Mrs. Moore was a real witness for his commitment to his religion. The second thing when he comes to talk about Miss Adela Quested to one of his friends, he describes her as pale women that no one finds himself attracted to her or may show any sort of admiration of her. She is not beautiful or tempting. The narrator compares between Aziz as an oriental, Adela and Ronny, this is what runs in Adela Quested's mind "what a handsome oriental he was, and no doubt his wife and children were beautiful too ... and she regretted that neither she nor Ronny had physical charm [researchers' emphasis]" (p. 66). The third one, he does not respond to her conversation about his wife and marriage in Islam. However, he finds himself annoyed by such questions that should not be asked by unmarried woman, but may be her questions reveal her bad intentions towards Dr. Aziz as a handsome oriental man; he does not want to uncover to her the reality of his wife's death to help to put an end to this disturbing conversation. The fourth one, the one who comes to arrest him, he is confessed that he feels Aziz's innocence but he has to follow the call of his duty." Mr. Haq, the Inspector of Police, flung open the door of their carriage and said in shrill tones, "Dr. Aziz, it is my highly painful duty [researchers italics] to arrest you" (p. 70). The fifth reason, one of the colonizers, Mr. Fielding, stands against his people to defend Dr. Aziz and he believes there is a sort of misunderstanding in the story of the rape. "I believe Dr. Aziz to be innocent. ... If he is guilty, I resign from my service, and leave India. I resign from the club now" (p. 210). However, Ronny insists that trial must proceed, ignoring the respectable position of Dr. Aziz between his people. All these evidences make the reader convinced about Dr. Aziz's innocence before Miss Adela confesses her mistake that Dr. Aziz never followed her into the caves. Dr. Aziz is released "without stain on his character" (p. 101). There are no evidences that would make the reader suspect Dr. Aziz's misbehavior.

Another characteristic that catches admiration of the reader is Dr. Aziz's tolerance as a Muslim when he has been asked to report Miss Adela to the court to regain his honor and reputation supposed to be tarnished by her accusation, he would not manifest any wish to take revenge. Here, Forester portrays the real image of Muslim who is committed to his religion and he is tolerant with his antagonists who led him to prison, if not death. Such tolerance and mannerism could not be found in the colonizers' attitudes, such as Ronny, who insists to lead Dr. Aziz to the court and trial. Ronny does not hesitate to push Dr. Aziz to the court despite scarcity of evidences and weakness of Adela's claims. A Passage to India portrays the real image of Muslim who is tolerant and sticks to his religion and culture. Dr. Aziz undoubtedly sets a good example of real Muslim and he seems more liberal and open to deal with his enemies explicitly. He may offer concession if it is involved with his personal concern, however, he would not negotiate the national interest and independence of his country. He could not victimize the national interest at the expense of personal interests or friendship. Aziz's words at the end of the novel were a clarion call for the colonizers to leave his country and his struggle to reach India independence is not questionable. Lazarus (2004) argues "Such straggle ranged from epic campaigns for libration in India ..., to armed struggle, guerrilla warfare and revolution, as was the case with Land Freedom Army (Mau Mau) in Kenya or the campaigns in Algeria, Indonesia, Malaysia, Vietnam, Angola, and Zimbabwe" (pp. 41-41).

Dr. Aziz insists on his nation independence and "India shall be a nation! No foreigners of any sort! Hindu, Muslim, Sikh, and all shall be one! Hurrah! Hurrah for India" (Forster, 1985, p. 141). Here we may recognize Dr. Aziz's concern about how he wants to see his country librated. If Dr. Aziz could not liberate his country; his sons 
would do whatever the years would pass." If I don't make you go Ahmad will, Karim will, if it is fifty five hundred years we shall get rid of you," Muslim could not hide their aggressive feeling against the colonizers and they would not negotiate independence of their country. Dr. Aziz as a Muslim incarnates the revolting one who seems honest and truthful in defending his national issues. He might be tolerant with enemies if it involves with his personal character, as what happened to him from Adela, he was tolerant to forgive her false accusation, but if it comes to his nation's interest, he shows no tolerance or negotiation. Friendship will not continue with the colonizers if the colonizers continue occupying any part of India. The journey that began in mysterious Marabar caves should be ended with spiritually enlightenment. From the beginning, Forster leads the reader from the darkness of the caves when he initiates his novel by describing Marabar caves to lead us to the mosque, the place of enlightenment. He has given a priority to the Mosque as a holly place for Muslims. It leads to the first meeting between Dr. Aziz and Mrs. Moore, to that sort of tolerance and respect between colonized and colonizers. It was the meeting of rationality, reasoning of mutual respect and mutual understanding. That meeting between Dr. Aziz and Mrs. Moors revealed the possibilities of living together with the consideration of the other values, religions and cultures.

Dr. Aziz manifests very significant fact that would not admit flattering or tolerance when he asked by Mr. Fielding "why can't be friends now? It is what's I want. It's what you want." The answer comes: "but the horses did not want it - they swerved a part; the earth didn't want, ... the temples, the tank, the jail, the palace, the birds, the carrion, the Guest House, that come into view as they issued from the gap and saw Mau beneath! They did not want it. They said in a hundred voices. "No, not yet," and the sky said, No, not there." (p. 141). Forster ends his novel with the above words, which highlight the impossibility of establishing a healthy relationship between the colonized and the colonizers. Dr. Aziz sets a good example for Muslim who respects the other social convections, religions and cultures, but he cannot risk the independence and freedom of his country to gain personal interests.

\section{Conclusion}

In A Passage to India, Forster attempted to settle a healthy relationship between British and Indians to bridge the cultural, religious and social gap between the two parties. However, the absence of tolerance and understanding from the British side, it makes the mission hard, if not impossible. Forster could not shift the realities of the situation in India to satisfy his own demands of establishing a healthy relationship. Further, he was led by the historical facts and creativity of fiction. Dr. Aziz as an Indian Muslim is the strong voice of a nation dominated by British occupying power that pays no concern to the religion and the culture of the Indian people. He is manifested as a defender of his religious rituals, places of worshipping, and a defender of his country's independence. Aziz appears the one who keeps his Muslim indigenous identity throughout the narrative. He could not trade the interests of his country to achieve a temporary friendship or personal interests. His voice was clear at the gate of the mosque as his political and national actions reflect his explicit situations towards his religion, nation, and his culture, which are revealed in many parts of the narrative.

Dr. Aziz is professional in his job as a doctor in Chandrapore and he acts as a liberal Muslim who recognizes well how to deal with people from different cultures and different religions, whether they are from his country's people or from the British people as his good treatment with Mr. Moors in the first meeting at the mosque. On the other hand, Mrs. Moors presents the brilliant side of the colonizers, the British people in her understanding for the Indian people' culture and religion, particularly Indian Muslim's culture. Forster showed in this narrative a passage to understand the Indian people with their diversity of origins, races and beliefs. He pulls our attention to the possibility of establishing a bridge of good relationship between both parties, if both parties, the British colonizers and the Indian people, believe in respect, mutual understanding, tolerance and humanity.

\section{References}

Abu-Baker, A. M. S. (2006). Rethinking Identity: The Colonizers in E. M. Forester's A Passage to India. Nebula 3, September, 2-3.

Ashcroft, B., Griffiths, G., \& Tiffin, H. (Eds.). (2002). Post-Colonial Studies. London and New York: Routledge.

Ashcroft, B., Griffiths, G., \& Tiffin, H. (Eds.). (2002). The Empire Writes Back: Theory and Practice in Post-Colonial Literature (2nd ed.). London and New York: Routledge.

Bhabha, H. (Ed.). (1990). Nation and Narration. London and New York.

Forster, E. M. (1985). A passage to India. Cambridge, Penguin classic.

Lazarus, N. (1999). Nationalism and Cultural Practice in Postcolonial World. Cambridge: Cambridge University Press. http://dx.doi.org/10.1017/CBO9780511585678 
Lazarus, N. (2004). The Cambridge Companion to Postcolonial Literary Studies. Cambridge: Cambridge University Press. http://dx.doi.org/10.1017/CCOL0521826942

Lin, L. (1997). The Irony of Colonial Humanism: A passage to India and the Politics of Posthumanism. ARIEL, 28(4), 133-153.

Loomba. A. (2005). Colonialism/Postcolonialism (2nd ed.). London and New York: Routledge.

Moosavinia. S. R. (2011). Texts and Politic: Postcolonial Revaluation of Two British Classics. The Journal of Teaching Language Skills, 33(3), 64.

Said, E. (1993). Culture and Imperialism. London: Chatto \& Windus.

\section{Copyrights}

Copyright for this article is retained by the author(s), with first publication rights granted to the journal.

This is an open-access article distributed under the terms and conditions of the Creative Commons Attribution license (http://creativecommons.org/licenses/by/3.0/). 